\title{
ANALISIS DAN PERANCANGAN SISTEM INFORMASI MANAJEMEN PADA AKADEMIS AMIK ASM LAKSI 31
}

\author{
Inayatulloh \\ Jurusan Sistem Informasi, Fakultas Ilmu Komputer, Binus University \\ Jl. KH. Syahdan No. 9, Palmerah, Jakarta Barat 11480. \\ inay@binus.ac.id
}

\begin{abstract}
The purpose of this article is to develop a computer-based Academic management information system for AMIK LAKSI 31 ASM by using Internet technology which functions to integrate internal processes with the academic learning process. The method of this research includes analysis of campus internal administration process of teaching and learning and development of a computer-based application that supports the process. In analyzing the campus administrative processes, several activities are carried out in order to get both information required and design of application built in accordance with needs. The result obtained is an academic information system model to be used in ASM AMIK LAKSI 31 based on web that can help the institution to improve efficiency and effectiveness of administrative processes and learning process.
\end{abstract}

Keywords: information systems, internet, academic systems, campus.

\begin{abstract}
ABSTRAK
Tujuan dari penelitian ini adalah membangun sebuah aplikasi sistem informasi manajemen Akademis AMIK ASM LAKSI 31 berbasis Komputer dengan menggunakan teknologi internet yang berfungsi untuk mengintegrasikan proses internal akademis dengan proses belajar mengajar. Metode penelitian yang dilakukan adalah melakukan analisis terhadap proses administrasi di internal kampus dengan proses kegiatan belajar mengajar serta mengembangkan aplikasi berbasis komputer yang mendukung proses tersebut. Dalam menganalisis proses adminsitrasi kampus dilakukan beberapa aktifitas dengan pihak kampus guna mendapatkan informasi yang dibutuhkan dan rancangan dari aplikasi yang akan dibangun yang sesuai dengan kebutuhan. Hasil yang dicapai adalah sebuah model sistem informasi akademis di AMIK ASM LAKSI 31 berbasiskan web yang dapat membantu lembaga kampus untuk meningkatkan efisiensi dan efektifitas proses administrasi dan proses belajar mengajar.
\end{abstract}

Kata kunci: sistem informasi, internet, sistem akademik, kampus. 


\section{PENDAHULUAN}

Pada era globalisasi sekarang ini, ilmu pengetahuan dan teknologi berkembang sangat pesat terutama dalam hal pemanfaatan teknologi informasi yang berbasis pada komputer. Sehingga perusahaan dituntut untuk dapat memanfaatkan teknologi informasi ini sebagai pendukung dalam peningkatan efektivitas dan efisiensi dari operasional perusahaan, yang sekaligus juga membantu pihak manajemen dalam pengambilan keputusan dan penentuan kebijakan yang dapat diandalkan perusahaan. demikian juga dengan institusi pendidikan atau kampus.

AMIK ASM LAKSI 31 adalah sebuah lembaga pendidikan tinggi yang memiliki dua akademi yakni Akademi Manajemen Informatika dan Komputer serta Akademi Sekretaris dan Manajemen. Kampus ini berlokasi di daerah Matraman, Jakarta Timur, dengan 400-500 mahasiswa aktif.

Tujuan dari penelitian ini adalah membuat sebuah model sistem informasi akademis dan membangun aplikasi berbasis komputer yang mendukung proses administrasi di lembaga tersebut. Dari penelitian ini diharapkan dapat meningkatkan efektifitas dan efisiensi kinerja di kampus AMIK ASM LAKSI 31.

\section{Kajian Teoritik}

\section{Sistem Informasi}

Menurut Jogiyanto (2001, p.1) sistem adalah suatu jaringan kerja dari prosedur-prosedur yang saling berhubungan, berkumpul bersama-sama untuk melakukan suatu kegiatan atau untuk menyelesaikan suatu sasaran yang tertentu. Sebuah sistem memiliki karakteristik tertentu yaitu mempunyai komponen, batasan sistem, lingkungan bagian luar sistem penghubung, masukan, keluaran, pengelolahan dan sasaran atau tujuan. Informasi menurut Jogiyanto (2000, p.8): adalah data yang diolah menjadi bentuk yang berarti bagi penerimanya dan bermanfaat dalam pengambilan keputusan saat ini atau akan datang. Kualitas dari sebuah informasi memiliki 3 (Tiga) persyaratan yaitu: (1) Akurat, sebuah informasi harus lepas dari kesalahan-kesalahan dan tidak memiliki dua makna yang berkaitan menyesatkan dan harus jelas mencerminkan maksudnya; (2) Tepat waktu, informasi yang dihasilkan atau dibutuhkan harus selalu up to date, tidak boleh terlambat, informasi yang terlambat tidak memiliki kualitas yang baik, sehingga jika digunakan sebagai dasar pengambilan keputusan akan berakibat fatal dan kemungkinan akan terjadi kesalahan yang sangat besar; dan (3) Relevan, informasi yang dihasilkan sesuai dan bermanfaat bagi penggunaannya. Relevansi bagi individu yang lainnya berbeda.

Pada saat ini penggunaan sistem informasi dengan menggunakan fasilitas komputer banyak digunakan diberbagai bidang, mulai dari ilmu pengetahuan hingga perkembangan ilmu teknologi oleh sebab itu masyarakat menyadari akan pentingnya sebuah sistem informasi dalam menunjang kinerja mereka. Menurut Jogiyanto (2001, p.11) sistem Informasi adalah suatu sistem di dalam suatu organisasi pengolahan transaksi harian, mendukung operasi yang bersufat manajerial dan kegiatan strategis dari laporan-laporan yang diperlukan.

Perancangan sistem informasi adalah gambaran perencanaan dan pembuatan sketsa atau pengaturan dari beberapa elemen yang terpisah kedalam satu kesatuan yang utuh dan berfungsi. Perancangan sistem adalah tahap setelah analisis dari siklus pengembangan sistem, pendefinisian dari kebutuhan fungsional dan persiapan untuk rancangan bagi implementasi, menggambarkan bagian suatu sistem dibentuk. Tujuan dari perancangan sistem ini adalah sebagai kegiatan atau kelanjutan dari analisis yang telah dilakukan dan untuk memberikan gambaran yang jelas dan lengkap. 


\section{Sistem Informasi Manajemen}

Menurut Jogiyanto (2000, p. 11) sistem informasi manjemen adalah kumpulan dari manusia dan sumber-sumber daya modal di dalam suatu organisasi yang bertanggung jawab mengumpulkan dan mengolah data untuk menghasilkan informasi yang berguna untuk semua tingkatan manajemen di dalam kegiatan perencanaan dan pengendalian.

Sistem Informasi Manajemen meningkatkan efisiensi pengolahan data yang digunakan oleh bagian akademis yang berdampak pada penigkatan efisensi proses bisnis perusahaan.

\section{METODE}

Metode penelitian yang digunakan adalah metode survei langsung ke lapangan dan wawancara dengan para pemakai dan pimpinan guna mendapatkan kebutuhan dari para pemakai. Bagian yang disurvei dan di wawancarai yaitu bagian nilai, bagian layanan, dan bagian pendaftaran. Selanjutnya dilakukan analisis sistem berjalan dan mengidentifikasi masalah yang dihadapi.

\section{HASIL DAN PEMBAHASAN}

Penelitian dimulai dengan menganalisis sistem berjalan dan mengidentifikasi masalah yang dihadapi pada administrasi mahasiswa.

Pendaftaran calon mahasiswa kebagian pendaftaran dengan mengisi formulir pendaftaran kemudian menyerahkannya ke bagian pendaftaran. Setelah itu bagian pendaftaran akan memberikan nomor induk mahasiswa (NIM) dan jadwal perkuliahan kepada mahasiswa. Dalam proses perkuliahan mahasiswa akan banyak berhubungan dengan bagian layanan baik yang berkaitan dengan daftar ulang, pembayaran kuliah dan lain sebagainya (Gambar 1). Bagian layanan biasanya menginformasikan tentang perkuliahan, status pembayaran, status mahasiswa dan lain-lain. Mahasiswa akan menanyakan ke bagian nilai tentang hasil ujian, protes nilai, perbaikan nilai dan lain-lain Bagian nilai akan mendistribusikan hasil ujian dalam bentuk Kartu Hasil Studi maupun transkrip nilai.

Berdasarkan hasil analisis sistem yang sedang berjalan dapat di identifikasi beberapa aktifitas di bagian akademis LAKSI 31 yaitu: (1) Adanya ketidaksesuaian data mahasiswa antar bagian pendaftaran, layanan dan bagian nilai, yang disebabkan karena adanya input berulang di masingmasing bagian; (2) Sering terjadi kehilangan data nilai mahasiswa; (3) Penyajian data yang tidak up to date ke pihak yayasan dan manajemen; dan (4) Kesalahan dalam pencetakan dokumen baik untuk mahasiswa, dosen maupun manajemen.

\section{Sistem yang Diusulkan}

Sistem yang dibangun dapat mengintegrasikan seluruh bagian akademis sehingga meningkatkan efektifitas dan efisiensi kinerja pada lembaga tersebut.

Seorang calon mahasiswa dapat menggunakan menu pendaftaran pada website yang dibangun dan mengisikan informasi yang dibutuhkan. Setelah melakukan pendaftaran, calon mahasiswa akan mendapatkan user ID dan password yang akan digunakan untuk transaksi berikutnya ke pihak kampus. Model sistem usulan ini diwakilkan dengan use case diagram berikut ini (Gambar 2). 


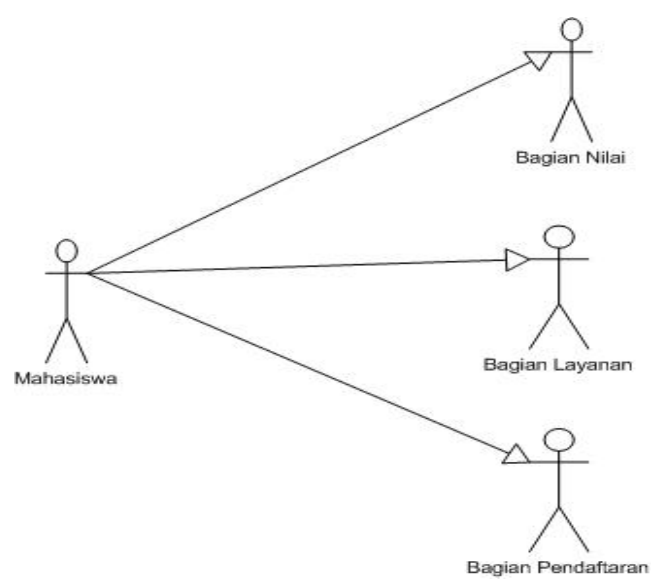

Gambar 1. Use case dengan mahasiswa sebagai aktor.

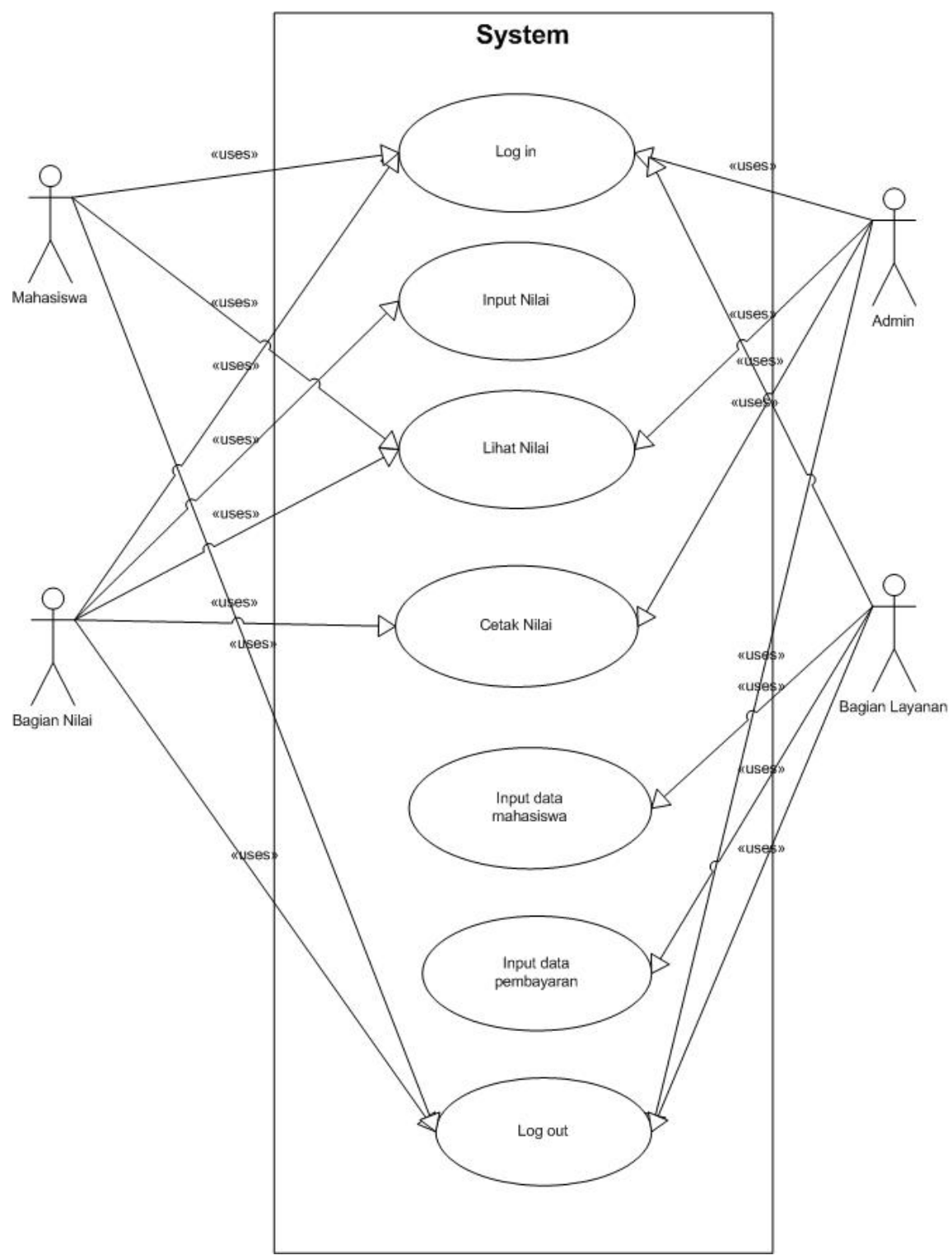

Gambar 2. Sistem informasi akademis AMIK ASM LAKSI 31 yang diusulkan. 
Dalam kaitannya dengan aplikasi sistem informasi akademis, diperlukan sebuah rancangan masukan atau interface antara user dengan sistem.layar masukannya seperti pada Gambar 3 berikut.

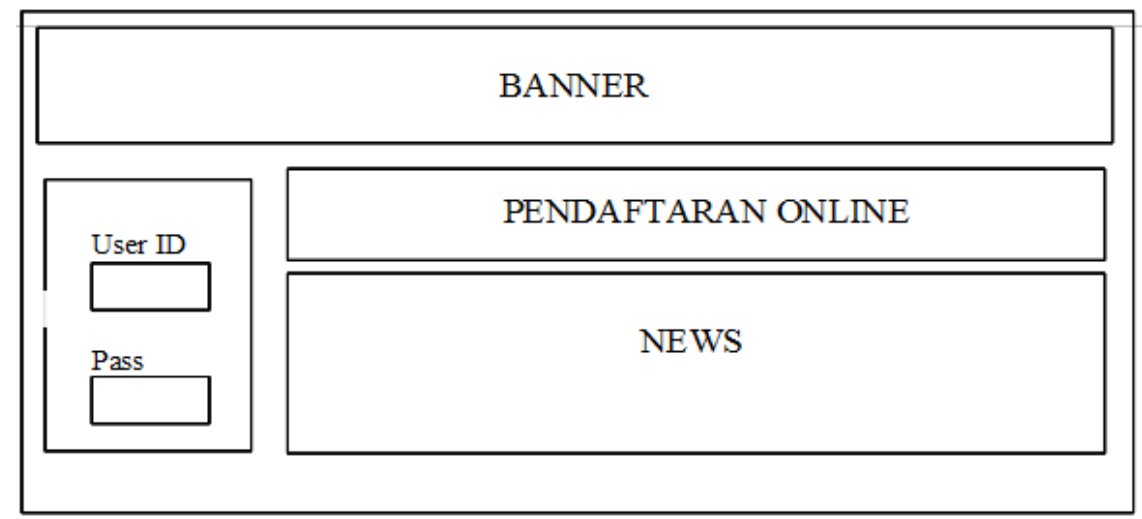

Gambar 3. Rancangan user interface sistem informasi akademis AMIK ASM LAKSI 31.

\section{PENUTUP}

Berdasarkan analisis masalah yang terjadi, penulis dapat mengidentifikasi hal-hal mendasar yang perlu diperbaiki. Dengan pembangunan sistem informasi akademis di AMIK ASM LAKSI 31 seluruh data yang berkaitan dengan bagian akademis seperti pendaftaran, layanan, pembayaran diintegrasikan pada satu database yang merupakan bagian dari sistem informasi akademis.

Dengan sistem ini pula interaksi, komunikasi dan informasi tidak harus dilakukan secara fisik karena sistem ini dibangun berbasis web sehingga informasi dapat diakses dimanapun dan kapanpun dengan dukungan teknologi internet.

Rencana pengembangan sistem kedepannya adalah mengintegrasikan sistem informasi akademis dengan $e$-learning system sehingga seluruh informasi yang dibutuhkan oleh mahasiswa baik yang berkaitan dengan administrasi perkuliahan maupun perkuliahan itu sendiri dapat di akses melalui satu aplikasi berbasis web.

\section{DAFTAR PUSTAKA}

Herlambang, S., \& Tanuwijaya, H. (2005). Sistem Informasi: Konsep Teknologi Dan Manajemen. Yogyakarta: Graha Ilmu.

Jogiyanto, H. M. (2000). Analisis dan Desain Sistem Informasi: Pendekatan Terstruktur. Yogyakarta: Andi Offset.

McLeod, R. (1995). Sistem Informasi dan Manajemen. (Hendra Teguh, terj.) . Jakarta: Prenhallindo. 